\title{
Quinolone Resistant Enterobacteriaceae and Pseudomonas in Environ- mental Water in Dhaka, Bangladesh
}

\author{
Haque $\mathrm{A}^{1}$, Tateda $\mathrm{K}^{1}$, Ishii $\mathrm{Y}^{1}$, Huda $\mathrm{Q}^{2}$, Islam $\mathrm{A}^{2}$, Miah $\mathrm{RA}^{3}$ \\ ${ }^{1}$ Department of Microbiology and Infectious Diseases, Toho University School of Medicine, Tokyo, Japan \\ ${ }^{2}$ Department of Anesthesiology \& Critical Care Medicine, Bangabandhu Sheikh Mujib Medical University, \\ Dhaka, Bangladesh \\ ${ }^{3}$ Department of Microbiology \& Immunology, Bangabandhu Sheikh Mujib Medical University, \\ Dhaka, Bangladesh
}

e-mail: haqamk@yahoo.com

\begin{abstract}
Pathogens that carry antibacterial resistant genes represent a threat for failure of antibiotic therapy and are associated with high mortality, morbidity and expenses. In Bangladesh, although quinolone resistance in clinical infections has been reported, environmental influence to this resistance is poorly known. Thus, to examine the existence of quinolone resistant bacterial strains in surface water in Dhaka, the study was conducted during June 2012 to January 2014. Surface water samples from Dhaka city were screened and isolated quinolone resistant Pseudomonas putida, Escherichia coli, Klebsiella pneumoniae, and Pseudomonas aeruginosa. Molecular and genetic analysis identified the resistant determinants in these isolates. The study suggests that potential role of water for the dissemination and transmission of resistant genes among microorganisms causing human and animal infections in Bangladesh.
\end{abstract}

Keywords: Quinolone, Resistant genes, Pseudomonas, Escherichia, Klebsiella

\section{Introduction}

Quinolone is one of the most commonly prescribed broad spectrum antimicrobial in the world at present era. This class of drug is currently used to treat a number of diseases including pyelonephritis, sexually transmitted diseases, prostatitis, chronic bronchitis, community-acquired and nosocomial pneumonia, intra-abdominal, pelvic, skin and tissue infections. ${ }^{1}$ But the increasing occurrence of microbial resistance to this drug is threatening confident use of quinolone in clinical infections.

The mechanism of action of quinolone is to inhibit bacterial de-oxyribo neucleic acid (DNA) replication and resistance to quinolones has been classified in three broad categories: (i) targetmediated (ii) plasmid mediated and (iii) chromosome mediated. Target mediated resistance is the most common and associated with specific mutations in DNA topoisomerase II (DNA gyrase: gyrA, gyrB) and topoisomerase IV, that exhibit high-level $(10-100$ fold $)$ resistance..$^{2-7}$ On the contrary, plasmid-mediated quinolone resistance (PMQR) mechanisms have been recently identified as an emerging clinical problem that causes low-level ( $\leq 10$ fold) resistance. ${ }^{2,}{ }^{8-16}$ PMQR mechanisms include target protection proteins of the qnr gene family: qnrA, qnrB, qnrC, qnrD and $q n r S^{9,17-20}$ and per $C$, enzymatic modification gene aac-(6')-Ib-cr and the efflux pump genes like oqxA, oqxB and qepA. In Bangladesh, quinolone is one of the most frequently prescribed drugs, and organisms resistant to this drug is increasingly high. $^{21}$ But precise information about the spreading of these resistant organisms influenced by water systems is poorly known. The objective of the study was to examine the existence of quinolone resistant bacterial strains in surface water in Dhaka. The study also determined the molecular characteristics of these isolates.

\section{Materials and Methods}

Water from the longest lake (about $4.5 \mathrm{~km}$ ) passing through the middle of Dhaka city, which 
receives waste water from the surrounding residents, commercial buildings and clinics, was chosen for sampling (figure 1). The study was conducted during June 2012 to January 2014.

Figure 1: Location of water sampling

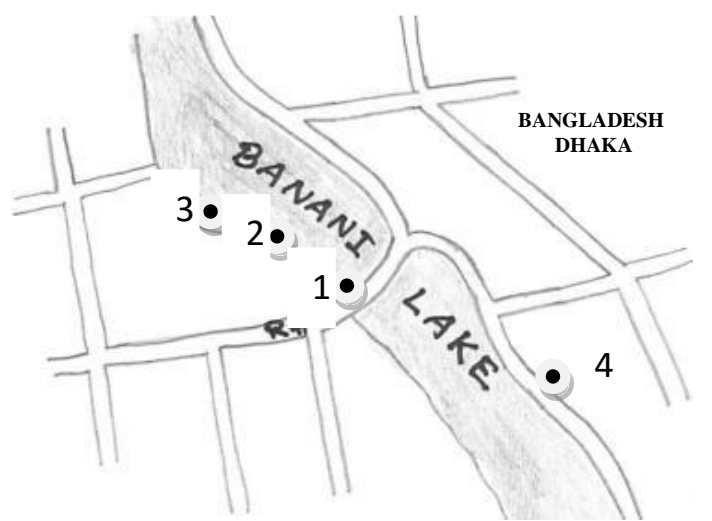

A total of four water samples were collected from opening of a pipe-line carrying waste water to Banani lake; edge of lake adjacent to the pipeline opening; middle of lake (approx. $50 \mathrm{~m}$ away from lake edge) and from the edge of the lake around one $\mathrm{km}$ away from the second sampling point adjacent to a slum and market places, where direct contact of human and animal to the lake water was evident, were screened. In all cases, 50 milliliter of water was filtered through $0.45-\mu \mathrm{m}$-pore-sized membranes. Membranes were suspended in $3 \mathrm{ml}$ distilled water inside sterile tubes. From each tube, $100 \mu \mathrm{l}$ suspensions were cultured on Mueller-Hinton agar. Growing colonies were counted, identified and tested for antimicrobial susceptibility by the BD Phoenix100 system (Nippon Becton Dickinson Co. Ltd., Tokyo). Minimum Inhibitory Concentrations (MICs) for ciprofloxacin (CIP) of each isolate were observed and the isolates those displayed MIC $\geq 4 \mu \mathrm{g} / \mathrm{ml}$ were considered CIP-resistant according to Clinical and Laboratory Standard Institute (CLSI) guideline and selected for further evaluation.

Genomic DNA was extracted from selected isolates using Wizard genomic DNA purification kit (Promega Corporation, USA) and the harvested DNAs were amplified by Polymerized Chain Reaction (PCR) in presence of specific primers.

Table I: Target genes, used primers and PCR reaction conditions

\begin{tabular}{|c|c|c|c|c|}
\hline Target & Primer & Sequence (5'-3') & Annealing Temperature (oC) & References \\
\hline \multirow[t]{2}{*}{ gyrA } & gyrA-QRDR-F & TCTGGATTATGCGATGTCGGTCAT & 54 & 22 \\
\hline & gyrA-QRDR-R & TCAGCCCTTCAATGCTGATGTCT & & \\
\hline \multirow[t]{2}{*}{ gyrB } & gyrB-QRDR-F & GCTGAGCGAATACCTGCTGG & 54 & 22 \\
\hline & gyrB-QRDR-R & TCGGTCATGATGATGATGCTGTGAT & & \\
\hline \multirow[t]{2}{*}{ parc } & parC-QRDR-F & ACTACTCCATGTACGTCATCATGGAC & 54 & 22 \\
\hline & parC-QRDR-R & CGCCACTTCGCGCAGGTTAT & & \\
\hline \multirow[t]{2}{*}{$q n r A$} & qnrA-f & ATTTCTCACGCCAGGATTTG & 54 & 23 \\
\hline & qnrA-r & TGCCAGGCACAGATCTTGAC & & \\
\hline \multirow[t]{2}{*}{$q n r B$} & qnrB-f & CGACCTKAGCGGCACTGAAT & 56 & 23 \\
\hline & qnrB-r & GAGCAACGAYGCCTGGTAGYTG & & \\
\hline \multirow[t]{2}{*}{ qnrC } & gnrC-f & GGGTTGTACATTTATTGAATCG & 47 & 19 \\
\hline & qnrC-r & CACCTACCCATTTATTTTCA & & \\
\hline \multirow[t]{2}{*}{$q n r D$} & qnrD-f & CGAGATCAATTTACGGGGAATA & 54 & 20 \\
\hline & qnrD-r & ACAAGCTGAAGCGCCTG & & \\
\hline \multirow[t]{2}{*}{ qnrS } & qnrS-f & ACTGCAAGTTCATTGAACAG & 56 & 23 \\
\hline & qnrS-r & GATCTAAACCGTCGAGTTCG & & \\
\hline \multirow[t]{2}{*}{$\operatorname{aac}\left(6^{\prime}\right)-1 b-c r$} & aac $\left(6^{\prime}\right)-\mathrm{lb}-\mathrm{cr}-\mathrm{f}$ & TTGCGATGCTCTATGAGTGGCTA & 58 & 24 \\
\hline & $\operatorname{aac}\left(6^{\prime}\right)-\mathrm{lb}-\mathrm{cr}-\mathrm{r}$ & CTCGAATGCCTGGCGTGTTT & & \\
\hline \multirow[t]{2}{*}{ oqxA } & oqxA-f & CTCGGCGCGATGATGCT & 57 & 23 \\
\hline & oqxA-r & CCACTCTTCACGGGAGACGA & & \\
\hline \multirow[t]{2}{*}{$o q \times B$} & oqxB-s & TTCTCCCCCGGCGGGAAGTAC & 64 & 23 \\
\hline & oqxB-a2 & CTCGGCCATTTTGGCGCGTA & & \\
\hline \multirow[t]{2}{*}{ qepA } & qepA-f & AACTGCTTGAGCCCGTAGAT & 54 & 25 \\
\hline & qepA-r & GTCTACGCCATGGACCTCAC & & \\
\hline
\end{tabular}

To determine the quinolone resistancedeterminants, like gyrA, gyrB, parC, qnrA, qnrB, $q n r C, q n r D, q n r S, \operatorname{aac}\left(6^{\circ}\right)-l b-c r, o q x A, o q x B$ and qep $A$ in the isolates. In case of $g y r A, g y r B$ and parC the resulting amplicons were further purified by QIA quick PCR purification kit (QI-
AGEN GmbH, Germany) and sequenced to compare with associated sequences in the Basic Local Alignment Search Tool (BLAST) database (http://blast.ncbi.nlm.nih.gov). Approval from the experiment and ethical committee of the institutes were obtained prior to conduct the study. 


\section{Results}

A total of 46 individual colonies were isolated from four water sample-cultures, where 10 $(21.7 \%)$ isolates showed MIC $\geq 4$ for CIP (data not shown). These bacteria were isolated from water collected from location no. 3 and 4 (figure 1). There were three Pseudomonas putida, two Escherichia coli, two Klebsiella pneumoniae, two Pseudomonas aeruginosa and one unknown isolate (table II).

Table II: Quinolone-resistant bacteria in water samples

\begin{tabular}{|c|c|c|c|}
\hline Locations & Isolate ID & Species & $\begin{array}{l}\text { Resistance determining } \\
\text { genes }\end{array}$ \\
\hline \multirow[t]{4}{*}{ Location - 3} & $\begin{array}{l}\text { TUM } \\
12598\end{array}$ & E. coli & gyrA \\
\hline & $\begin{array}{l}\text { TUM } \\
12599\end{array}$ & E. coli & gyrA \\
\hline & TUM & $K$. & $\operatorname{gyr} A$, oqxA, oqxB, \\
\hline & 13741 & $\begin{array}{l}\text { pneumo- } \\
\text { nia }\end{array}$ & $a a c\left(6^{\prime}\right) l b-c r$ \\
\hline \multirow[t]{14}{*}{ Location - 4} & TUM & Un- & $q n r A$ \\
\hline & 15734 & known & \\
\hline & TUM & $K$ & gyrA, OqxA \\
\hline & 15735 & $\begin{array}{l}\text { pneumo- } \\
\text { nia }\end{array}$ & \\
\hline & TUM & P. putida & $o q x A$ \\
\hline & 15736 & & \\
\hline & TUM & P. putida & $q n r A$ \\
\hline & 15737 & & \\
\hline & TUM & P. aeru- & gyrA, qnrA, qnrS \\
\hline & 15738 & ginosa & \\
\hline & TUM & P. putida & $q n r S$ \\
\hline & 15739 & & \\
\hline & TUM & P. aeru- & $q n r A$ \\
\hline & 15740 & ginosa & \\
\hline
\end{tabular}

Three $P$. putida bacteria were containing three different types of resistant genes like oqxA, qnrA and $q n r S$, whereas, both $E$. coli were containing same resistant gene gyrA. Both of $K$. pneumonia strains were encoded with multiple resistant determinants including complex of gyrA, oqxA, $o q x B, a a c\left(6^{\prime}\right) l b-c r$ and complex of gyrA, oqxA. Isolated $P$. aeruginosa (TUM 15738) were contacting three resistant genes gyrA, qnrA and qnrS in its plasmid, where another one (TUM 15740) was containing only qnrA. Unknown strain was containing single resistant gene $q n r A$. Among the resistant determinant, gyrA was most frequent $(5 / 10,50 \%)$ in isolates, followed by $q n r A(4 / 10$, $40 \%)$, oqxA (3/10, 30\%), qnrS (2/10, 20\%), oqxB $(1 / 10,10 \%)$ and $a a c\left(6^{\prime}\right) l b-c r(1 / 10,10 \%) . g y r B$, parC, $q n r B, q n r C, q n r D$ and $q e p A$ were not observed in any isolates in environmental water samples from Bangladesh. DNA sequences of gyrA in E. coli and K. pneumoniae were compared with the associated sequences in GenBank. (Accession numbers AF052254 and AF052258 respectively).

\section{Discussion}

In this study, the isolation of quinolone resistant bacteria from two out of four environmental water samples collected from a lake in Dhaka. Ten quinolone resistant gene encoding strains were isolated, where one strain was not identified by BD Phoenix-100 system and others included three P. putida, two E. coli, two K. pneumoniae, two $P$. aeruginosa. The current study is the first evidence for the existence of quinolone resistant $P$. putida, $K$. pneumoniae and $P$. aeruginosa in environmental water in Bangladesh. A previous study reported CIP-resistant E. coli in hospital waste water in Bangladesh ${ }^{26}$, and also did not find $q n r$ gene in their E. coli isolates, similar to the current study result. But they showed co-existence of both $g y r A$ and $\operatorname{gyr} B$ in isolates and we found only gyrA resistant gene in our E. coli isolates. However, taking together it could be concluded that in disseminating $E$. coli in Bangladesh water quinolone resistance is mainly determined by mutation of DNA gyrase that exhibit high-level of resistance to quinolone group of drugs. Another recent study showed increased rate of CIP resistance in common clinical isolates like E. coli, $P$. aeruginosa, $K$. pneumonia, etc. in Bangladesh. ${ }^{27}$ In this study, it was to be found that high-level of resistance determining gene gyrA in those clinically relevant bacteria in environment indicating important influence of environmental bacteria in harvesting and spreading of resistant genes among clinical isolates.

It is a long running debate in epidemiology field whether environmental organisms significantly influence clinical infection or not. However, with the current expanded understanding it is now clear that dissemination of resistant organisms and/or their resistant determinants from humans to animals and vice versa, often involve environmental pathways including foodstuffs, animal wastes and water sources. Thus, the environment plays an important role in both the emergence and spread of microbial resistance. ${ }^{28}$ Zurfluh $\mathrm{K}$ et al showed drug resistant isolates from river water in Switzerland were comparable with those 
isolates from clinics, healthy human carriers and food-producing animals. ${ }^{29}$ It could be applicable in other parts of the world, including Bangladesh. We observed DNA gyrase targeted resistance in $50 \%$ of isolates, warned a careful observation of this mutation in clinical isolates. Plasmidmediated quinolone resistance (PMQR) was observed in eight environmental isolates in Bangladesh. Although PMQR mechanisms confer low level resistance to quinolones, 2, 8-16 but they are thought to enable the occurrence of chromosomal mutation in bacteria which then lead to increased resistance levels, as high as upto 250 -fold. $2,12,14$ Unlike target-mediated resistance, which is transmitted vertically from generation to generation, PMQR can be transmitted horizontally (through bacterial conjugation) as well as vertically. Moreover, plasmids that confer quinolone resistance typically carry additional genes that cause resistance to other antimicrobials. $^{9}, 11,12,14$ Quinolone resistant E.coli (TUM 12598 and TUM 12599) and K. pneumonia (TUM 13741) are also included as ESBLproducing bacteria according to our previous study.$^{30}$ Our finding is comparable with the study of Zurfluh et al. where they showed that ESBL producing $E$. coli in their collected environmental water samples were carrying resistant determinants against quinolones. Concomitant quinolone and other class of drugs resistant bacteria are not uncommon in clinical setting in Bangladesh, as Rahman M et al. reported 46.3\% MDRSalmonella typhi were less susceptible to CIP. ${ }^{32}$

\section{Conclusion}

This study provides evidence for the importance of the water-related environment as a reservoir of emerging threat of quinolone resistance and raises worrisome of increasing prevalence of quinolone resistant organisms in clinics in Bangladesh. More attention and investigations in environmental and clinical settings are required to challenge the threat by quinolone resistant bacteria.

\section{References}

1. Dalhoff A. Resistance surveillance studies: A multifaceted problem-the fluoroquinolone example. Infection. 2012; 40: 239-62.
2. Drlica K, Hiasa H, Kerns R, Malik M, Mustaev A, Zhao X. Quinolones: Action and resistance updated. Curr. Top Med Chem. 2009; 9: 981-98.

3. Hooper DC. Mode of action of fluoroquinolones. Drugs. 1999; 58(2): 6-10.

4. Hooper DC. Mechanisms of action of antimicrobials: Focus on fluoroquinolones. Clin Infect Dis. 2001; 32(1): S9-S15.

5. Anderson VE, Osheroff N. Type II topoisomerases as targets for quinolone antibacterials: Turning Dr. Jekyll into Mr. Hyde. Curr Pharm Des. 2001; 7: 337-53.

6. Fournier B, Zhao X, Lu T, Drlica K, Hooper DC. Selective targeting of topoisomerase IV and DNA gyrase in Staphylococcus aureus: Different patterns of quinolone-induced inhibition of DNA synthesis. Antimicrob Agents Chemother. 2000; 44: 2160-65.

7. Price LB, Vogler A, Pearson T, Busch JD, Schupp $\mathrm{JM}$, Keim P. In vitro selection and characterization of Bacillus anthracis mutants with high-level resistance to ciprofloxacin. Antimicrob Agents Chemother. 2003; 47: 2362-65.

8. Hooper DC. Emerging mechanisms of fluoroquinolone resistance. Emerging Infect Dis. 2001; 7: $337-$ 41.

9. Martinez L, Pascual A, Jacoby GA. Quinolone resistance from a transferable plasmid. Lancet. 1998; 351: 797-99.

10. Martinez-Freijo P, Fluit AC, Schmitz FJ, Grek VS, Verhoef J, Jones ME. Class I integrons in Gramnegative isolates from different European hospitals and association with decreased susceptibility to multiple antibiotic compounds. J Antimicrob Chemother. 1998; 42: 689-96.

11. Wang M, Tran JH, Jacoby GA, Zhang Y, Wang F, Hooper DC. Plasmid-mediated quinolone resistance in clinical isolates of Escherichia coli from Shanghai, China. Antimicrob Agents Chemother 2003; 47: 2242-48.

12. Robicsek A, Jacoby GA, Hooper DC. The worldwide emergence of plasmid-mediated quinolone resistance. Lancet Infect Dis. 2006; 6: 629-40.

13. Poirel L, Cattoir V, Nordmann P. Is plasmidmediated quinolone resistance a clinically significant problem? Clin Microbiol Infect. 2008; 14: 295-97.

14. Strahilevitz J, Jacoby GA, Hooper DC, Robicsek A. Plasmid-mediated quinolone resistance: A multifaceted threat. Clin Microbiol Rev. 2009; 22: 664-89. 
15. Rodriguez-Martinez JM, Cano ME, Velasco C, Martinez-Martinez L, Pascual A. Plasmid-mediated quinolone resistance: An update. J Infect Chemother. 2011; 17: 149-82.

16. Carattoli A. Plasmids and the spread of resistance. Int J Med Microbiol. 2013; 303: 298-304.

17. Hata M, Suzuki M, Matsumoto M, Takahashi M, Sato K, Ibe S, et al. Cloning of a novel gene for quinolone resistance from a transferable plasmid in Shigella flexneri 2b. Antimicrob Agents Chemother. 2005; 49: 801-03.

18. Jacoby GA, Walsh KE, Mills DM, Walker VJ, Oh H, Robicsek A, et al. qnrB, another plasmid-mediated gene for quinolone resistance. Antimicrob Agents Chemother. 2006; 50: 1178-82.

19. Wang M, Guo Q, Xu X, Wang X, Ye X, Wu S, et al. New plasmid-mediated quinolone resistance gene, qnrC, found in a clinical isolate of Proteus mirabilis. Antimicrob Agents Chemother. 2009; 53: 1892-97.

20. Cavaco LM, Hasman H, Xia S, Aarestrup FM. qnrD, a novel gene conferring transferable quinolone resistance in Salmonella enterica serovar Kentucky and Bovismorbificans strains of human origin. Antimicrob Agents Chemother .2009; 53: 603-08.

21. Biswas M, Roy DN, Tajmim A, Rajib SS, Hossain M, Farzana F, et al. Prescription antibiotics for outpatients in Bangladesh: a cross-sectional health survey conducted in three cities. Ann Clin Microbiol Antimicrob. 2014; 13: 15.

22. Aoike N, Saga T, Sakata R, Yoshizumi A, Kimura S, Iwata $\mathrm{M}$, et al. Molecular characterization of extraintestinal Escherichia coli isolates in Japan: relationship between sequence types and mutation patterns of quinolone resistance-determining regions analyzed by pyrosequencing. J Clin Microbiol. 2013; 51: 1692-98.

23. Gacharna N, Black TA, Miller GH, Hooper DC. Temporal appearance of plasmid-mediated quinolone resistance genes. Antimicrob Agents Chemother. 2009; 53:1665-66.

24. Park CH, Robicsek A, Jacoby GA, Sahm D, Hooper DC. Prevalence in the United States of aac $\left(6^{\prime}\right) \mathrm{Ib}-\mathrm{cr}$ encoding a ciprofloxacin-modifying enzyme. Antimicrob Agents Chemother. 2006; 50: 3953-55.

25. Kim HB, Park CH, Kim CJ, Kim EC, Jacoby GA, Hooper DC. Prevalence of plasmid-mediated quinolone resistance determinants over a nine-year period. Antimicrob Agents Chemother. 2009; 53: 639-45.

26. Akter F, Amin MR, Osman KT, Anwar MN, Karim MM, Hossain MA. Ciprofloxacin-resistant Escherichia coli in hospital wastewater of Bangladesh and prediction of its mechanism of resistance. World $\mathbf{J}$ Microbiol Biotechnol. 2012; 28:827-34.

27. Hossain MA, Musa AK, Shamsuzzaman AK, Mahmud MC. Increasing trend of ciprofloxacin resistance amongst common bacterial isolates at Mymensingh Medical College and Hospital. Mymensingh Med J. 2003; 12: 48-50.

28. Finley RL, Collignon P, Larsson DG, McEwen SA, Li XZ, Gaze WH, et al. The scourge of antibiotic resistance: the important role of the environment. Clin Infect Dis. 2013; 57: 704-10.

29. Zurfluh K, Hächler H, Nüesch-Inderbinen M, Stephan R. Characteristics of extended-spectrum $\beta$ lactamase- and carbapenemase-producing Enterobacteriaceae isolates from rivers and lakes in Switzerland. Appl Environ Microbiol. 2013; 79: 3021-26.

30. Haque A, Yoshizumi A, Saga T, Ishii Y, Tateda K. ESBL-producing Enterobacteriaceae in environmental water in Dhaka, Bangladesh. J Infect Chemother .2014; 20: 735-37.

31. Zurfluh K, Abgottspon H, Hächler H, NüeschInderbinen M, Stephan R. Quinolone resistance mechanisms among extended-spectrum betalactamase (ESBL) producing Escherichia coli isolated from rivers and lakes in Switzerland. PLoS One .2014; 9: e95864.

32. Rahman M, Siddique AK, Shoma S, Rashid H, Salam MA, Ahmed QS, et al. Emergence of multidrug-resistant Salmonella enterica serotype Typhi with decreased ciprofloxacin susceptibility in Bangladesh. Epidemiol Infect. 2006; 134: 433-38. 